\title{
Web-based macroseismic intensity study in Turkey - entries on Ekşi Sözlük
}

\author{
Deniz Ertuncay, Laura Cataldi, and Giovanni Costa \\ Department of Mathematics and Geosciences, University of Trieste, via E. Weiss 4, 34128 Trieste, Italy \\ Correspondence: Deniz Ertuncay (dertuncay@units.it)
}

Received: 15 June 2020 - Discussion started: 16 July 2020

Revised: 8 January 2021 - Accepted: 19 January 2021 - Published: 22 February 2021

Abstract. Ekşi Sözlük is one of the most visited websites in Turkey. Registered users of the website share their knowledge about any topic. In this study, we collect the user entries on the topic of 20 earthquakes in Turkey and the surrounding area. Entries with city and district level information are converted to intensity values. Shake maps of the earthquakes are created by using a ground motion to intensity conversion equation. User entries and created shake maps are compared. It is found that entries correlate with the predicted intensities. It is also found that local soil conditions and building types have an amplifier effect on entries on the website. Several entries on the earthquake topics have magnitude estimations. The difference between predicted and observed intensities also varies with distance. Users are able to predict the magnitudes of the earthquakes with \pm 0.54 misfit. This study shows that Ekşi Sözlük has the potential to be a reliable source of macroseismic intensity for the earthquakes in Turkey if the felt reports are collected with a predetermined format.

\section{Introduction}

Many national seismic data providers (ARSO, 2020; British Geological Survey, 2020; Sbarra et al., 2010; Swiss Seismological Service, 2020; ZAMG, 2020), along with international organizations (European-Mediterranean Seismological Centre, EMSC; Bossu et al., 2017; United States Geological Survey, USGS; Wald et al., 2012) collect web-based macroseismic survey data. Various questions are asked, in the form of a questionnaire, to individuals who are willing to share their experience after an earthquake. The answers are then converted to macroseismic intensity scales, and felt maps are created as an end product of the earthquake. The data may be collected continuously, as in EMSC and USGS, and after a specific earthquake (Bossu et al., 2008, 2015; Goltz et al., 2020; Liang et al., 2017).

In Turkey, the Disaster and Emergency Management Presidency of Turkey (AFAD) is the only data collector for macroseismic intensity. However, felt reports of AFAD are rare and lack location information. On the other hand, Turkish data providers were the seventh largest data providers (third in Europe) to the EMSC in 2018.

Social media data are also used for earthquake science (Crooks et al., 2013; Earle et al., 2010, 2012; Mendoza et al., 2010; Robinson et al., 2013). Integration of multi-language social media data provides additional information about the earthquake location in near-real time (Zielinski et al., 2012). Twitter was used in the Sichuan earthquake to have rapid information about the earthquake ( $\mathrm{Li}$ and Rao, 2010). In the 2011 Tohoku earthquake, Twitter allowed the rapid spread of information about the earthquake (Miyabe et al., 2012). Arapostathis et al. (2018) revealed that intensity maps created using Twitter data had a high correlation with predicted intensity maps for the 2017 Lesbos earthquake. Fayjaloun et al. (2020) integrated Twitter data with strong motion recordings to compare the felt area predicted by shake maps and real observations in France.

Internet users in Turkey are also sharing their experiences of earthquakes in other websites such as Ekşi Sözlük (https://eksisozluk.com/, last access: 17 February 2021). Ekşi Sözlük is a collaborative dictionary. To be a full member of the website, newly registered users are required to write 10 entries on existing topics. Then, the entries are analyzed according to the rules of the site. By doing that, Ekşi Sözlük provides relatively reliable information to the visitors. It was the 14th most visited website in Turkey in 2019 (Alexa Inter- 
net, 2020). Even though there are entries in other languages, the main language used on the website is Turkish. Users of the website create topics on earthquakes that they have felt and also for major earthquakes occurring around the world.

In this study, we collect entries from various major earthquakes in western Turkey. Entries that provide city and district information are analyzed. Macroseismic intensity maps are created for the earthquakes by using the magnitude information. Analyzed entries are compared with predicted intensities. Furthermore, we collect the magnitude guesses of the users and compare them with the real results.

\section{Data}

Earthquake information of the origin time, magnitude, latitude, longitude, and depth of the events is gathered from EMSC and the Kandilli Observatory and Earthquake Research Institute Regional Earthquake-Tsunami Monitoring Center. This information is used for the creation of the shake map (Sect. 3) and calculation of the distance between the epicenter and districts of the entries.

To analyze the entries in the earthquake topics, 20 titles with the highest number of entries for earthquakes that have occurred in western Turkey and the surrounding area are selected (Table 1). Western Turkey is chosen due to higher numbers of people with access to the internet (Turkish Statistical Institute, 2019). Entries that provide location information in district levels are filtered. These entries are labeled according to the modified Mercalli-Cancani-Sieberg (MCS) scale (Sieberg, 1930). The MCS scale is a way of describing the effect of an earthquake, and the intensity of an earthquake can be determined for a site of interest. Unlike the magnitude of an earthquake, the intensity value $(I)$ can be different depending on various parameters such as epicentral distance, local soil conditions, and building type. For instance, $I$ (MCS) class 1, which is the lowest class, means that the earthquake is not felt, except by very few under especially favorable conditions, whereas class 12 , which is the highest class, means a total destruction. Several entries also provide a guess from the user about the magnitude of the earthquake.

Topics are created right after the origin time of the earthquake (Table 1). Since the website does not provide the time information precisely to the second in the entries, we do not exactly know the time gap between the origin time of the earthquake and the creation time of the topic. However, almost all topics that we analyzed are created either during the same minute as the origin time or a minute later. Several topics are created for some earthquakes that are widely felt in many regions. Moderators of the website combine the topics into the proper topic title, which is generally the date of the earthquake and the nearest major city, or sea, to the epicenter. Topics are created with the same format, which is as follows:

10-aralik-2019-balikesir-depremi-6277350

day-month-year-location-earthquake-topicID
When an aftershock is felt, the entries indicate the existence of an aftershock. In these cases, we subdivided the earthquake into multiple earthquakes by adding a number to the end of the topicID. Several MCS labels, along with the entry, can be seen as follows:

Topic: 20-aralik-2018-yalova-depremi-5881852

Entry: "I felt it in Gebze (Kocaeli) but I was the only one.

Lights are not swinging; none of my family members have felt it."

I (MCS): 1

Topic: 20-subat-2019-canakkale-depremi-5947040

Entry: "I felt it strongly. I think it was M4.4 ...

I (MCS): 2

Topic: 30-kasim-2018-yalova-depremi-5861331

Entry: "I thought my neighbor downstairs hit the ceiling of their apartment with a hammer ..."

I (MCS): 3

Topic: 26-eylul-2019-istanbul-depremi-6191375

Entry: "We saw the rattling windows not only in our office building but also in the neighboring building. I tried to walk forward, but instead I staggered backwards ..."

\section{I (MCS) 4}

Topic: 6-subat-2017-canakkale-depremi-5296414

Entry: "We felt it strongly. We evacuated the office building."

I (MCS): 5

Topic: 26-eylul-2019-istanbul-depremi-6191375

Entry: "I was at Avcılar. I saw debris falling from a building..."

I (MCS): 6

Hereafter, earthquakes are represented by their topicID. In Table 2, we present information about the entries. Thread 5392358 is excluded from further analysis due to lack of entries. 
Table 1. Topics of various earthquakes on the Ekşi Sözlük site. The first entry, additionally, gives the information of the creation time (with the date, given as $\mathrm{dd} / \mathrm{mm} / \mathrm{yyyy}$, and the time stamp of the entry in universal coordinated time) of the topic. $\Delta t$ is the time between the origin time of the earthquake and the creation of the topic of the earthquake. Entries under the first entry do not provide the seconds in the time stamp. Magnitudes are moment magnitude $\left(M_{\mathrm{W}}\right)$, unless otherwise stated.

\begin{tabular}{|c|c|c|c|c|c|c|c|}
\hline Topic & Origin time & First entry & $\begin{array}{r}\Delta t \\
(\min )\end{array}$ & Magnitude & $\begin{array}{r}\text { Event } \\
\text { latitude }\end{array}$ & $\begin{array}{r}\text { Event } \\
\text { longitude }\end{array}$ & $\begin{array}{r}\text { Depth } \\
(\mathrm{km})\end{array}$ \\
\hline 19-mayis-2011-simav-depremi-2814519 & 19/05/2011 20:15:22 & 19/05/2011 20:15 & $\leq 1$ & 5.7 & 39.14 & 29.1 & 0 \\
\hline 7-haziran-2012-tekirdag-depremi-3418720 & 06/07/2012 20:54:26 & 06/07/2012 20:55 & $\leq 1$ & 5.1 & 40.85 & 27.92 & 14 \\
\hline 8-ocak-2013-ege-denizi-depremi-3673799 & 01/08/2013 16:16:06 & 01/08/2013 16:17 & $\leq 1$ & 5.7 & 39.65 & 25.48 & 8.4 \\
\hline 16-kasim-2015-istanbul-depremi-4966334 & $16 / 11 / 2015$ 15:45:43 & $16 / 11 / 201515: 46$ & $\leq 1$ & 3.9 & 40.83 & 28.76 & 7.7 \\
\hline 25-haziran-2016-yalova-depremi-5137587 & 25/06/2016 05:40:11 & $25 / 06 / 201605: 41$ & $\leq 1$ & 4.1 & 40.7 & 29.21 & 9 \\
\hline 15-ekim-2016-istanbul-depremi-5208242 & 15/10/2019 08:18:32 & 15/10/2019 08:19 & $\leq 1$ & 4.9 & 42.19 & 30.71 & 10 \\
\hline 6-subat-2017-canakkale-depremi-5296414 & 02/06/2017 03:51:39 & 02/06/2017 03:54 & $>1$ & 5.3 & 39.56 & 26.02 & 6 \\
\hline 6-subat-2017-canakkale-depremi-5296414-2 & 02/06/2017 10:58:00 & 02/06/2017 10:59 & $\leq 1$ & 5.1 & 39.51 & 26.07 & 6 \\
\hline 12-haziran-2017-izmir-depremi-5388936 & 06/12/2017 12:28:39 & 06/12/2017 12:29 & $\leq 1$ & 6.2 & 38.85 & 26.35 & 10 \\
\hline 17-haziran-2017-izmir-depremi-5392358 & 17/06/2017 03:40:36 & 17/06/2017 03:42 & $>1$ & 4.6 & 38.91 & 26.22 & 9 \\
\hline 17-haziran-2017-izmir-depremi-5392358-2 & 17/06/2017 19:50:04 & $17 / 06 / 201719: 54$ & $>1$ & 5.2 & 38.85 & 26.44 & 7 \\
\hline 30-kasim-2018-yalova-depremi-5861331 & $30 / 11 / 201802: 36: 35$ & $30 / 11 / 201802: 37$ & $\leq 1$ & 4 & 40.58 & 28.98 & 9 \\
\hline 20-aralik-2018-yalova-depremi-5881852 & 20/12/2018 06:34:25 & 20/12/2018 06:35 & $\leq 1$ & 4.4 & 40.6 & 29.97 & 8 \\
\hline 25-ocak-2019-izmir-depremi-5919561 & 25/01/2019 20:20:33 & 25/01/2019 20:21 & $\leq 1$ & 4.2 & 38.58 & 27.1 & 18 \\
\hline 20-subat-2019-canakkale-depremi-5947040 & 20/02/2019 18:23:27 & $20 / 02 / 201918: 24$ & $\leq 1$ & 5 & 39.62 & 26.43 & 8 \\
\hline 8-agustos-2019-izmir-depremi-6135297 & 08/08/2019 08:39:07 & 08/08/2019 08:39 & $\leq 1$ & 4.6 & 38.02 & 26.85 & 6 \\
\hline 20-agustos-2019-ankara-depremi-6148327 & 20/08/2019 02:07:35 & 20/08/2019 02:08 & $\leq 1$ & $3.2\left(M_{1}\right)$ & 39.89 & 33.04 & 10 \\
\hline 25-agustos-2019-ankara-depremi-6155192 & 25/08/2019 18:42:26 & 25/08/2019 18:42 & $\leq 1$ & $3.5\left(M_{1}\right)$ & 40.04 & 32.8 & 5 \\
\hline 24-eylul-2019-istanbul-depremi-6189374 & 24/09/2019 08:00:22 & 24/09/2019 08:00 & $\leq 1$ & 4.5 & 40.88 & 28.21 & 4 \\
\hline 26-eylul-2019-istanbul-depremi-6191375 & 26/09/2019 10:59:24 & 26/09/2019 11:00 & $\leq 1$ & 5.6 & 40.88 & 28.21 & 5 \\
\hline 10-ekim-2019-yalova-depremi-6208576 & 10/10/2019 16:52:03 & $10 / 10 / 201916: 52$ & $\leq 1$ & 4 & 40.68 & 29.25 & 13.9 \\
\hline 10-ekim-2019-yalova-depremi-6208576-2 & 10/10/2019 17:04:39 & 10/10/2019 17:04 & $\leq 1$ & $3.1\left(M_{1}\right)$ & 40.7 & 29.26 & 5 \\
\hline 10-ekim-2019-yalova-depremi-6208576-3 & 10/10/2019 17:09:40 & 10/10/2019 17:10 & $\leq 1$ & $3.3\left(M_{1}\right)$ & 40.7 & 29.25 & 2 \\
\hline 10-ekim-2019-yalova-depremi-6208576-4 & 10/10/2019 19:32:07 & $10 / 10 / 201919: 32$ & $\leq 1$ & $3.7\left(M_{1}\right)$ & 40.69 & 29.26 & 12 \\
\hline 10-aralik-2019-balikesir-depremi-6277350 & 12/10/2019 20:14:02 & 12/10/2019 20:15 & $\leq 1$ & 4.6 & 39.45 & 29.93 & 8 \\
\hline 10-aralik-2019-balikesir-depremi-6277350-2 & 12/10/2019 20:24:05 & $12 / 10 / 201920: 24$ & $\leq 1$ & 4.3 & 39.44 & 29.91 & 11.3 \\
\hline 10-aralik-2019-balikesir-depremi-6277350-3 & 12/10/2019 20:46:18 & $12 / 10 / 201920: 47$ & $\leq 1$ & 4 & 39.44 & 29.9 & 14.3 \\
\hline
\end{tabular}

\section{Method}

For each event, analyzed entries are compared with reference instrumental intensity values. Instrumental intensity is a forecast of the macroseismic intensity and is calculated as a function of input ground motion parameters. Instrumental intensity is defined following the methodology from Cataldi et al. (2021).

First, instrumental intensity is defined using an independent data set, relative to 90 events that occurred in Italy between 1972 and 2016, with the local magnitude over 3.4. The definition consists of extracting an empirical relationship between observed intensity and ground motion parameters, namely the peak ground velocity (PGV) and peak ground acceleration (PGA). PGV and PGA are observed from ground motion records. Integration and/or differentiation of the seismic record are done, depending on the seismic recorder, and then the two parameters are measured. Ground motion parameter values are extracted from the data set (Gallo et al., 2014) and are correlated with expert-assessed intensity values taken from the Italian Macroseismic Database (Locati et al., 2016). The regression is performed using Gaussian naïve Bayes (GNB) classifiers. This methodology provides a full probability distribution over integer intensity classes. In other words, for each input parameter value, the probability of occurrence is calculated for $I$ classes. The intensity forecast is then taken as the class with the highest associated probability.

Second, a piece-wise function, relating ground motion values to intensity, is extracted from the GNB results obtained for the Italian data set, so that each forecasted $I$ class is associated with a specific range of ground motion parameter values. For PGV and PGA, the used intervals are presented in Table 3.

As for the events reported in Table 1, PGV and PGA values are calculated from information on seismic origins using ground motion prediction equations (GMPEs). GMPEs are a set of equations that allow us to predict the ground motion parameters based on various earthquake and site-related information. Values obtained through GMPEs are then assigned to the corresponding $I$ class according to Table 3 . The PGA-based function is used for events with $M_{\mathrm{w}}<5$; the PGV-based one is used for events with $M_{\mathrm{w}}>5$. 
Table 2. Extracted information from entries of each topicID. The numbers of the entry, with the city and district information along with the Mercalli-Cancani-Sieberg (MCS) scale value, are shown. The unique numbers of the cities and the districts of these cities are given, respectively. The maximum MCS, minimum MCS, and average MCS of these entries, together with the entries with magnitude guesses, regardless of location information, are also shown.

\begin{tabular}{|c|c|c|c|c|c|c|c|}
\hline topicID & $\begin{array}{r}\text { No. of } \\
\text { entry }\end{array}$ & $\begin{array}{r}\text { No. of } \\
\text { city }\end{array}$ & $\begin{array}{l}\text { No. of } \\
\text { district }\end{array}$ & $\begin{array}{r}\text { Max } \\
\text { MCS }\end{array}$ & $\begin{array}{r}\text { Min } \\
\text { MCS }\end{array}$ & $\begin{array}{l}\text { Avg. } \\
\text { MCS }\end{array}$ & $\begin{array}{r}\text { No. of } \\
\text { mag }\end{array}$ \\
\hline 2814519 & 78 & 11 & 37 & 5 & 2 & 2.65 & 2 \\
\hline 3418720 & 38 & 4 & 28 & 4 & 1 & 2.18 & 1 \\
\hline 3673799 & 73 & 6 & 33 & 4 & 2 & 2.30 & 3 \\
\hline 4966334 & 51 & 2 & 23 & 5 & 2 & 2.53 & 4 \\
\hline 5137587 & 85 & 5 & 21 & 4 & 1 & 2.68 & 6 \\
\hline 5208242 & 26 & 4 & 15 & 3 & 1 & 2.12 & 6 \\
\hline 5296414 & 20 & 6 & 14 & 4 & 1 & 2.10 & 0 \\
\hline $5296414-2$ & 20 & 6 & 14 & 5 & 1 & 2.40 & 0 \\
\hline 5388936 & 151 & 12 & 60 & 6 & 1 & 2.26 & 9 \\
\hline 5392358 & 3 & 1 & 3 & 2 & 2 & 2.00 & 1 \\
\hline $5392358-2$ & 46 & 7 & 22 & 5 & 1 & 1.98 & 9 \\
\hline 5861331 & 42 & 4 & 23 & 4 & 2 & 2.48 & 3 \\
\hline 5881852 & 53 & 4 & 27 & 4 & 1 & 2.21 & 2 \\
\hline 5919561 & 63 & 3 & 18 & 4 & 1 & 2.37 & 13 \\
\hline 5947040 & 62 & 7 & 38 & 4 & 1 & 1.90 & 5 \\
\hline 6135297 & 101 & 6 & 32 & 5 & 1 & 2.17 & 16 \\
\hline 6148327 & 30 & 1 & 6 & 4 & 1 & 2.87 & 7 \\
\hline 6155192 & 129 & 1 & 9 & 4 & 1 & 2.27 & 5 \\
\hline 6189374 & 152 & 5 & 41 & 5 & 1 & 2.59 & 9 \\
\hline 6191375 & 233 & 12 & 57 & 6 & 1 & 2.74 & 1 \\
\hline 6208576 & 68 & 3 & 18 & 5 & 1 & 2.15 & 15 \\
\hline $6208576-2$ & 12 & 3 & 10 & 3 & 1 & 2.00 & 0 \\
\hline $6208576-3$ & 25 & 2 & 12 & 2 & 1 & 1.96 & 0 \\
\hline $6208576-4$ & 29 & 3 & 10 & 3 & 1 & 2.10 & 2 \\
\hline 6277350 & 47 & 8 & 26 & 3 & 1 & 1.94 & 10 \\
\hline $6277350-2$ & 19 & 7 & 13 & 5 & 1 & 2.16 & 1 \\
\hline $6277350-3$ & 10 & 3 & 8 & 5 & 1 & 2.20 & 1 \\
\hline
\end{tabular}

Table 3. Table of PGA and PGV value intervals for the calculation of $I$; values are taken from Cataldi et al. (2021).

\begin{tabular}{lrrrrrrrrrr}
\hline$I$ & 1 & 2 & 3 & 4 & 5 & 6 & 7 & 8 & 9 & 10 \\
\hline $\mathrm{PGA}_{\min }\left(\mathrm{cm} \mathrm{s}^{-2}\right)$ & & 0.32 & 1.91 & 6.31 & 17.78 & 52.48 & 85.11 & 141.25 & 269.15 & 575.44 \\
$\mathrm{PGA}_{\max }\left(\mathrm{cm} \mathrm{s}^{-2}\right)$ & $<0.32$ & 1.91 & 6.31 & 17.78 & 52.48 & 85.11 & 141.25 & 269.15 & 575.44 & 1148.15 \\
$\mathrm{PGV}_{\min }\left(\mathrm{cm} \mathrm{s}^{-1}\right)$ & & 0.01 & 0.10 & 0.28 & 0.74 & 2.57 & 5.75 & 9.77 & 21.38 & 39.81 \\
$\mathrm{PGV}_{\max }\left(\mathrm{cm} \mathrm{s}^{-1}\right)$ & $<0.01$ & 0.10 & 0.28 & 0.74 & 2.57 & 5.75 & 9.77 & 21.38 & 39.81 & 70.789 \\
\hline
\end{tabular}

\section{Results}

All topics are analyzed with the methods explained in Sects. 2 and 3. A total of four of them are represented in this section. We compare the computed intensities with the entries, and we also compare them with the EMSC felt report maps. Furthermore, magnitude guesses are compared with the measured magnitudes.

\subsection{Lesbos earthquake - 12 June 2017}

The Lesbos earthquake on 12 June $2017, M_{\mathrm{W}}=6.2$, (topicID - 5388936) occurred south of the Lesbos island and was felt largely in Turkey. Izmir is the closest city to epicenter of the earthquake; thus, the topic is created as being the 12 June 2017 Izmir earthquake in Ekşi Sözlük. There are 151 entries with city and district information. The farthest felt entry is from the Pursaklar district ( $\approx 580 \mathrm{~km}$ ) of Ankara (MCS is 1$)$. The entry with the largest MCSs is from the Konak $(\approx 80 \mathrm{~km})$ and Karaburun districts $(27 \mathrm{~km})$ of Izmir and the Yunus Emre district $(\approx 85 \mathrm{~km})$ of Manisa (Fig. 1). In the Karaburun dis- 


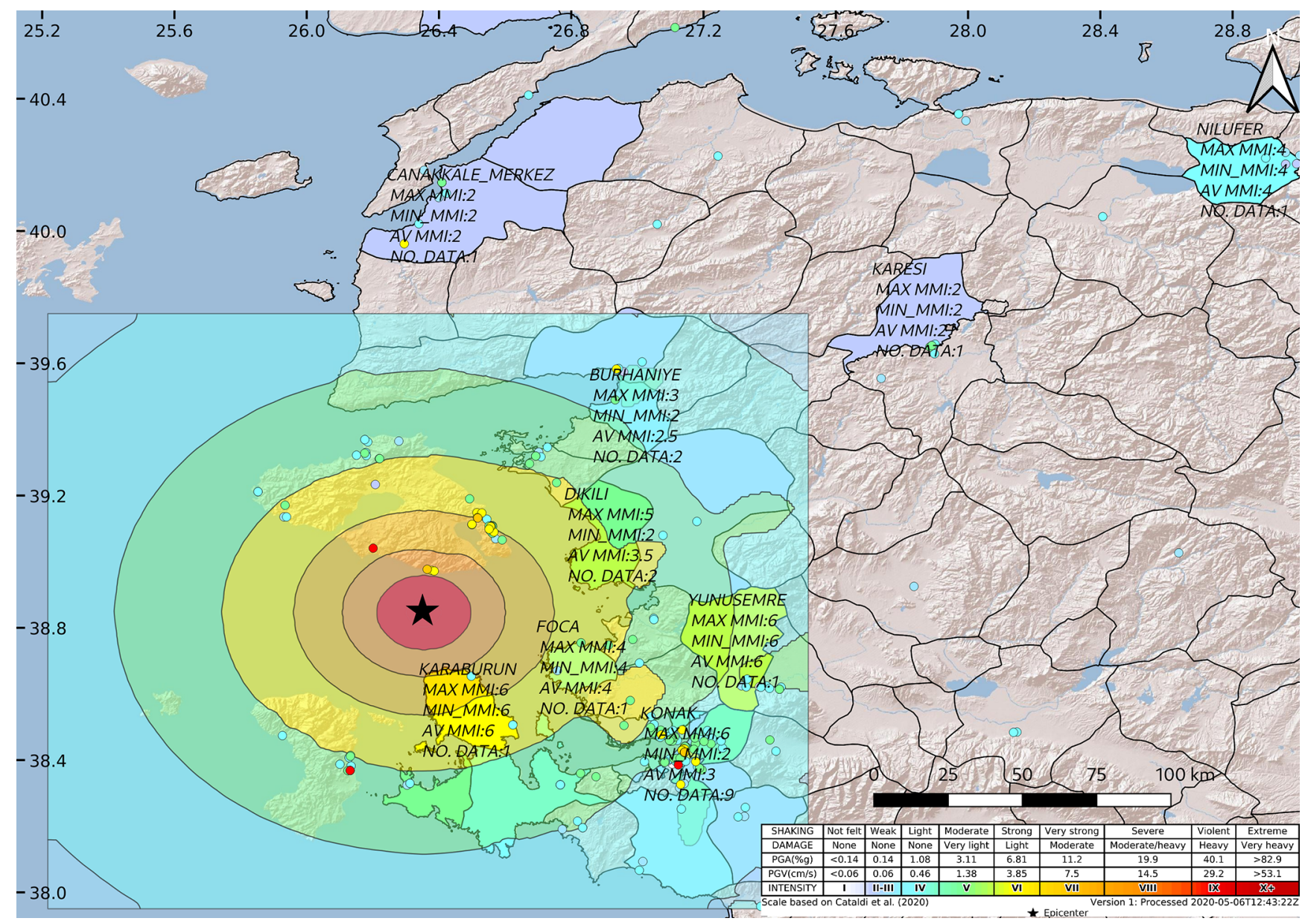

Figure 1. Intensity map of the 12 June 2017 Lesbos earthquake with labeled entries. Entries are plotted to district level polygons since the exact locations of the data providers are unknown. Felt reports of the earthquake submitted to EMSC are given at the top of the labeled entries (created using QGIS).

trict, users were overbalanced during the earthquake, with many others inside a government office. Cracks in the walls and in the columns of the buildings are reported in two entries. The intensity map has a strong correlation with the labeled maximum MCS scale. Minimum MCSs are hard to interpret since some of the entries contain only words, such as "strongly felt", which are labeled as MCS being equal to 2 . Such entries lowered the average MCSs. Hence, we preferred to rely on maximum MCS labels.

A large amount of entries are written in Istanbul (Fig. 2). Almost all districts of the city have maximum MCS of 2, except Avcrlar district which has 3. This can be linked to the loose soil of the Avc1lar district of Istanbul. The Avcilar district was affected by the $M_{\mathrm{w}}=7.4$ İzmit earthquake of 1999. More than $10 \%$ of the buildings were either destroyed or damaged in the earthquake (Tezcan et al., 2002). It is due to the amplified shaking and soft sediments in the district (Tezcan et al., 2002; Ergin et al., 2004; Akarvardar et al., 2009).
There are 635 felt reports at AFAD for the earthquake. It is hard to interpret the data due to a lack of location information about the earthquake. There are intensity values of 11 in several reports, which is highly unlikely for magnitude 6.2 earthquake. EMSC have 755 felt reports for the earthquake (Fig. 1). Intensities in EMSC are larger than the ones in Ekşi Sözlük. There are I 5 reports in faraway cities, such as Istanbul and Sofia, which is an unlikely intensity for the earthquake. Furthermore, there are various intensity $10+$ reports in EMSC in Izmir. However, there is no report that supports such destruction in Izmir. Various masonry buildings have cracks in their walls but none of them have collapsed (9 Eylül report, Department of Engineering of Dokuz Eylul University, 2017).

\subsection{Ankara earthquake - 25 August 2019}

The Ankara earthquake on 25 August 2018, $M_{l}=3.5$, (topicID - 6155192) occurred south of the Keçiören district of Ankara and was felt locally in the city (Fig. 3). There are 


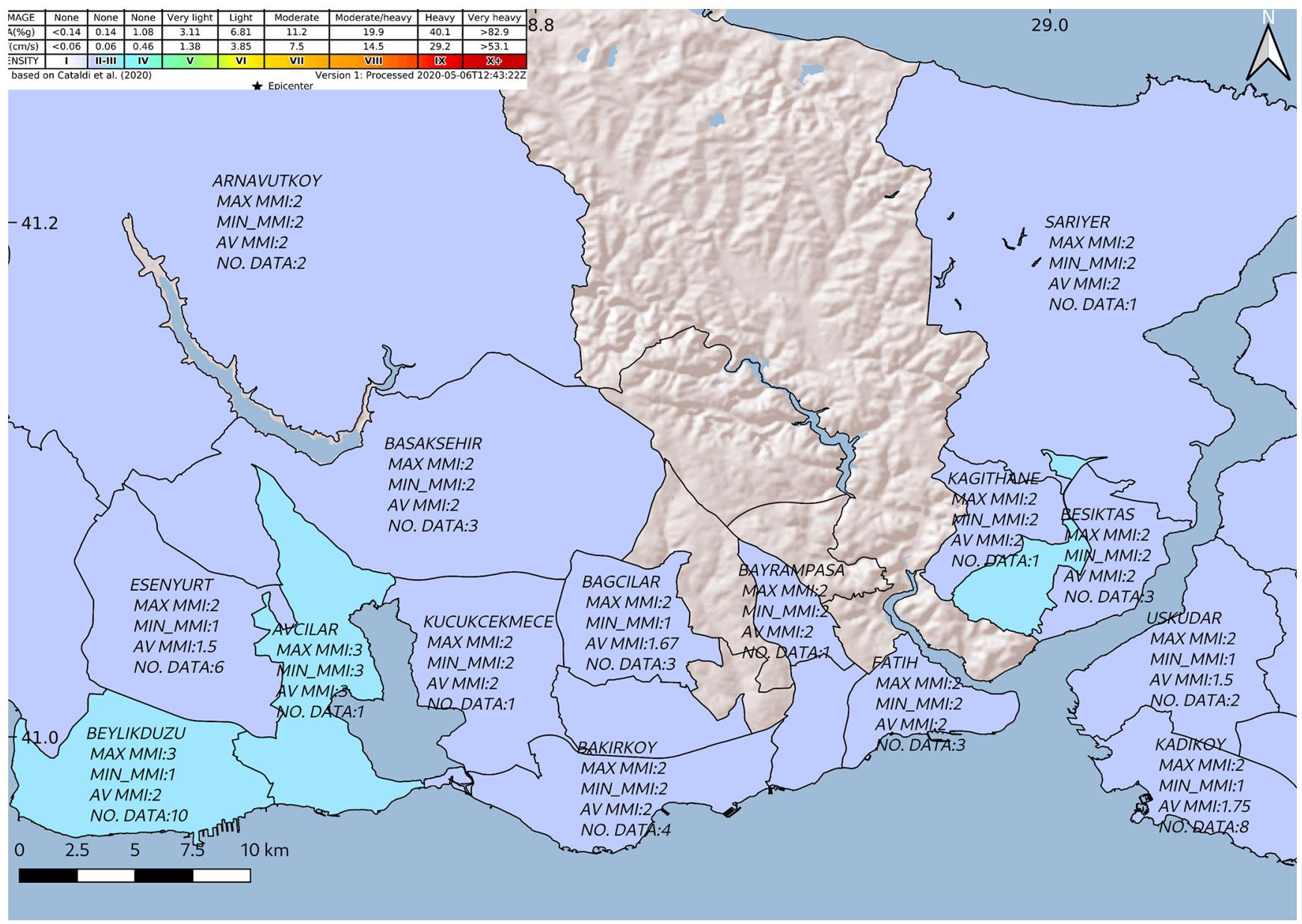

Figure 2. Intensity map of 12 June 2017 Lesbos earthquake with labeled entries on the western side of Istanbul. Entries are plotted to district level polygons (created using QGIS.)

129 entries with city and district information. The depth of the earthquake is measured as being $5 \mathrm{~km}$. Even though there are large number of magnitude 3.5 earthquakes in Turkey, this was felt by many inhabitants since the hypocenter was located beneath the city of Ankara, and the earthquake had a shallow hypocentral depth. Due to the shallow depth, almost all districts provided relatively higher maximum MCS values.

There is no felt report in AFAD for the earthquake. There are 205 felt reports in EMSC (Fig. 3). The intensity measures on Ekşi Sözlük and from EMSC are highly correlated for the earthquake.

\subsection{Istanbul earthquake - 26 September 2019}

The 26 August 2019 Istanbul earthquake, $M_{\mathrm{w}}=5.6$, (topicID - 6191375) occurred south of the Silivri district of Istanbul and was felt largely in Istanbul and the surrounding cities (Fig. 3). There are 233 entries with city and district information. A minaret of a mosque in the Avcilar district of Istanbul collapsed (Hürriyet, 2019) and more than 450 buildings were damaged (Anadolu Agency, 2019). The earthquake provided the largest data set, with 233 comments with district level information from 12 cities. This is due to the fact that Istanbul is the most crowded city in Turkey, and the earthquake happened during the daytime (13:59 local time).

In Silivri, Büyükçekmece, and Avcılar districts, maximum MCS from the entries are labeled as 6. The intensity map predicts MCS 4.5 for the Avcrlar district. Local soil conditions, as explained in Sect. 4.1, may have a role on the exaggerated intensities in the entries written in Avc1lar.

In the Beşiktaş district, a maximum MCS of 5 is given in three entries. All of them are due to the evacuation of the buildings. A total of two of these entries are from high-rise office buildings, which probably caused extra panic due to the swaying of the tall buildings. The evacuation was also influenced by panic and is also one of the reasons for the maximum MCS of 5 that was given in the entries from the Fatih, Beyoğlu, and Kadıköy districts. In the Kartal district, MCS is 5 is due to objects falling from shelves. 


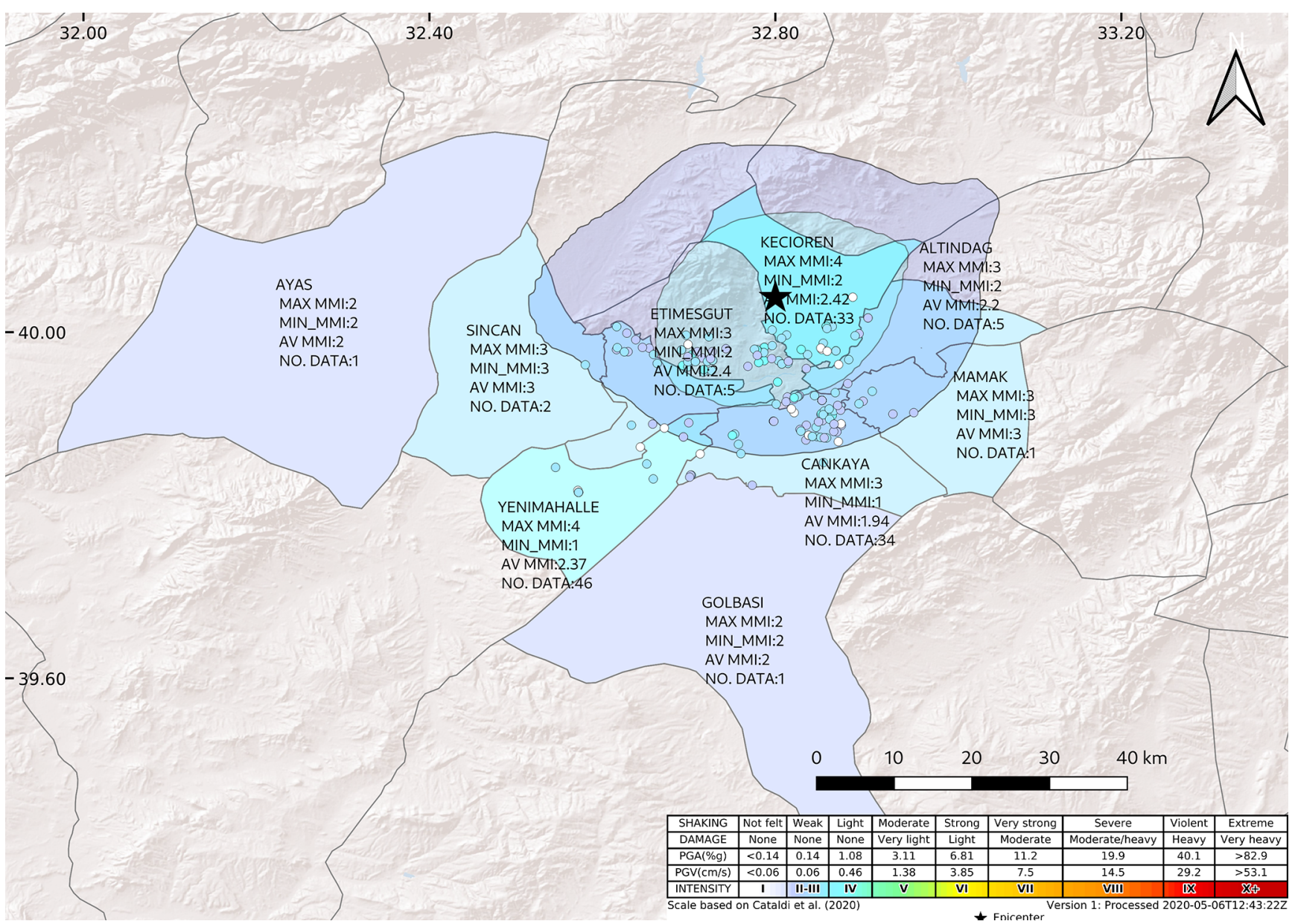

Figure 3. Intensity map of the 25 August 2019 Ankara earthquake with labeled entries. Entries are plotted to district level polygons. Felt reports of the earthquake submitted to EMSC are at the top of the labeled entries (created using QGIS).

There are 70 felt reports in AFAD for the earthquake with a maximum intensity of 6, which is also the case on the Ekşi Sözlük site. In EMSC (Fig. 4), there are 2027 felt reports. In Istanbul, intensities are reported slightly higher with respect to Ekşi Sözlük reports. However, it is important to keep in mind that felt reports in EMSC are designed for this purpose, whereas in Ekşi Sözlük, the entries are written in a free format. In general, EMSC and Ekşi Sözlük are correlated in the Büyükçekmece and Avcılar districts. On the other hand, intensities are at least one grade lower in Ekşi Sözlük reports with respect to EMSC reports. There are large intensity values in cities such as Eskişehir $(d>200 \mathrm{~km})$ and Denizli $(d>350 \mathrm{~km})$. Large intensities in such far away distances for a $M_{\mathrm{w}}=5.6$ earthquake are unlikely.

\subsection{Yalova earthquake - 10 October 2019}

The 10 October 2019 Yalova earthquake, $M_{\mathrm{W}}=4.0$, (topicID - 6208576) occurred north of Yalova and was felt in Istanbul and the surrounding cities (Fig. 5). There are 68 entries with city and district information. Most of the entries are from the Kartal district of Istanbul and Gebze district of Kocaeli. In Gebze, the maximum MCS is 5, which is due to the panicked evacuation of a building. The rest of the entries in Gebze are claiming MCS levels of 2 and 3. The MCS scale is highly subjective and depends on an individual's feelings about earthquakes. Thus, users on the Ekşi Sözlük site are writing their feelings without using any guidelines. As in this example, unexpectedly high MCSs may occur.

There is no felt report in AFAD records for the earthquake. There are 1371 felt reports in EMSC records (Fig. 5). The intensity measures from Ekşi Sözlük users and EMSC records are correlated for Gebze, Kartal, Kadıköy, and Kücükçekmece districts. There are more data points in EMSC than in Ekşi Sözlük, which provides more information about different regions of the area, especially in the city of Yalova. There are several unexpectedly high intensity values for Istanbul in EMSC. 


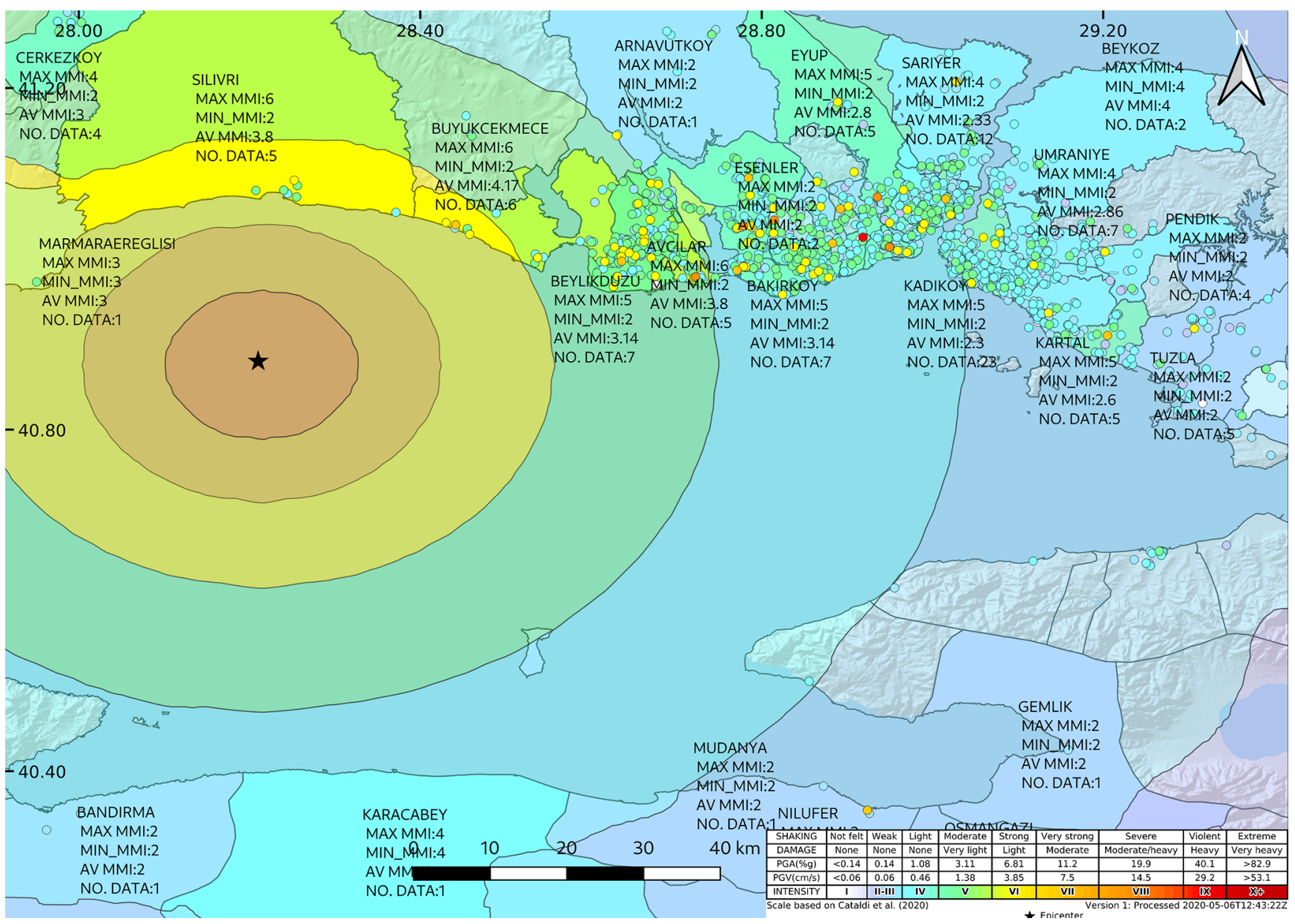

Figure 4. Intensity map of the 26 September 2019 Istanbul earthquake with labeled entries. Entries are plotted to district level polygons. Felt reports of the earthquake submitted to EMSC are at the top of the labeled entries (created using QGIS).

\subsection{Magnitude guesses}

Users on the Ekşi Sözlük site also provide magnitude information that depends on their feelings. We include entries without location information. In various entries, the magnitude is guessed at with a semi-infinite range, such as "... it was at least 4.8 " for the 20 February 2019 Dardanelles earthquake (topicID - 5947040), or it is guessed within a full range, such as "... it is between 2-3 ..." for the 10 December 2019 Balıkesir earthquake (topicID - 6277350). In semidefinite guesses, the given edge value is considered. The average of the range is used when it is provided.

Measured magnitudes, along with the user guesses, can be seen in Fig. 6. The average misfit between the guessed magnitudes and measured magnitudes is 0.54 . We also examine the earthquakes with at least two guesses. Misfit is calculated, and, again, it is 0.54 . However, it is important to keep in mind that guesses with a range are averaged, and various guesses are semi-definite.

\section{Discussion and conclusion}

In this study, we gather entries from earthquake topics on the Ekşi Sözlük site. In the threads, users discuss the earthquake and their experiences. We filter the entries with city and district level information that can be converted to the MCS scale. When there is an aftershock, it is discussed in the same thread on the website. In such incidences, we divide the topic into sub-topics.

In total, 27 earthquakes are chosen for the analysis. Intensity maps are created for the earthquakes, and the correlation between the predicted intensities and the entries which were converted to intensity values are roughly interpreted. The values are mapped to the districts of Turkey due to lack of precise location information. Interpretation is done over maximum MCSs. Uncertainty with respect to the data points in terms of location varies, depending on the epicenter of the earthquake and the positioning of the governmental district.

To have an insight into the relation between the predicted MCS and observed MCS, a rough relation between the two parameters and the distance is analyzed. Observation points 


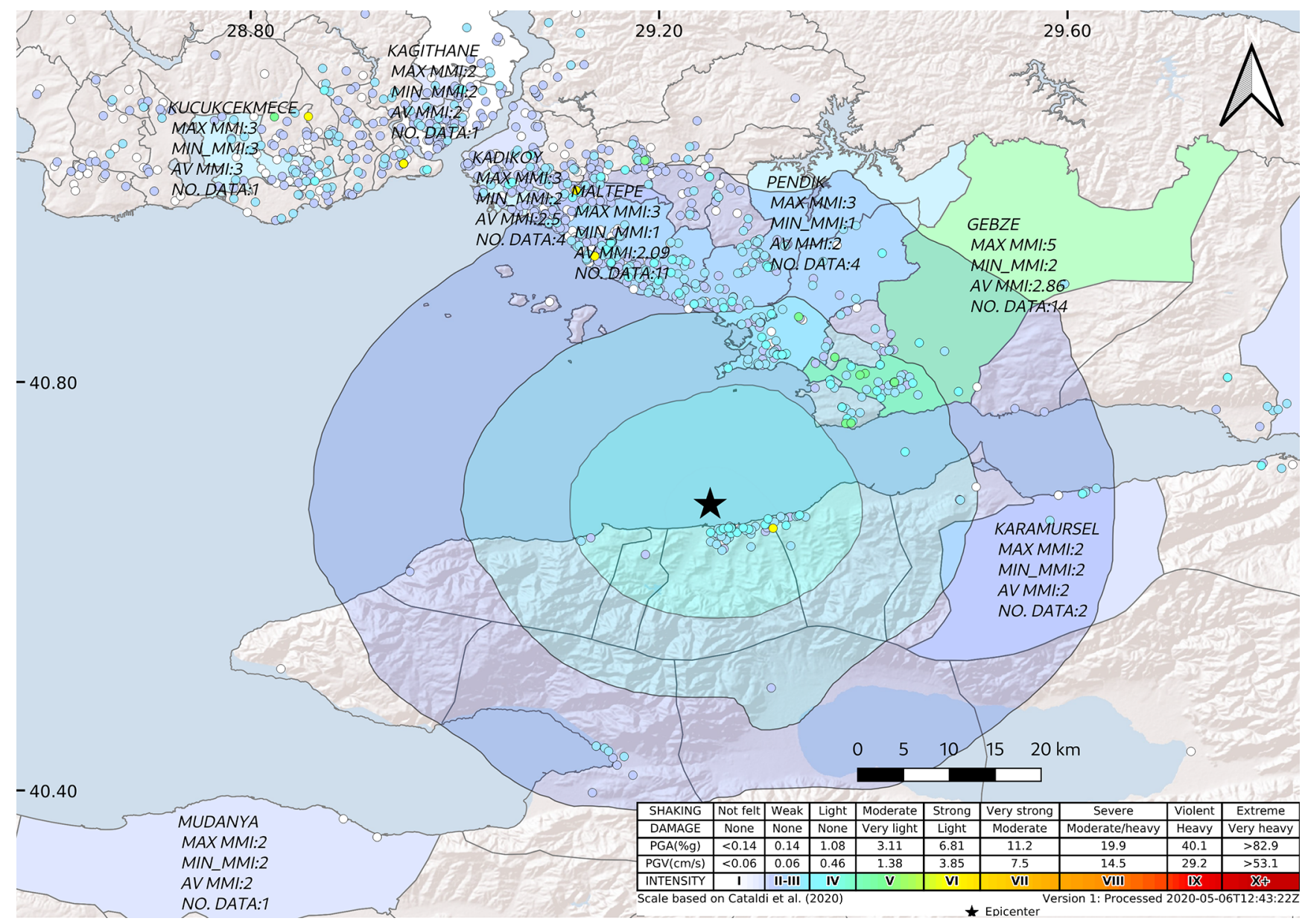

Figure 5. Intensity map of the 10 October 2019 Yalova earthquake with labeled entries. Entries are plotted to district level polygons. Felt reports of the earthquake submitted to EMSC are at the top of the labeled entries (created using QGIS).

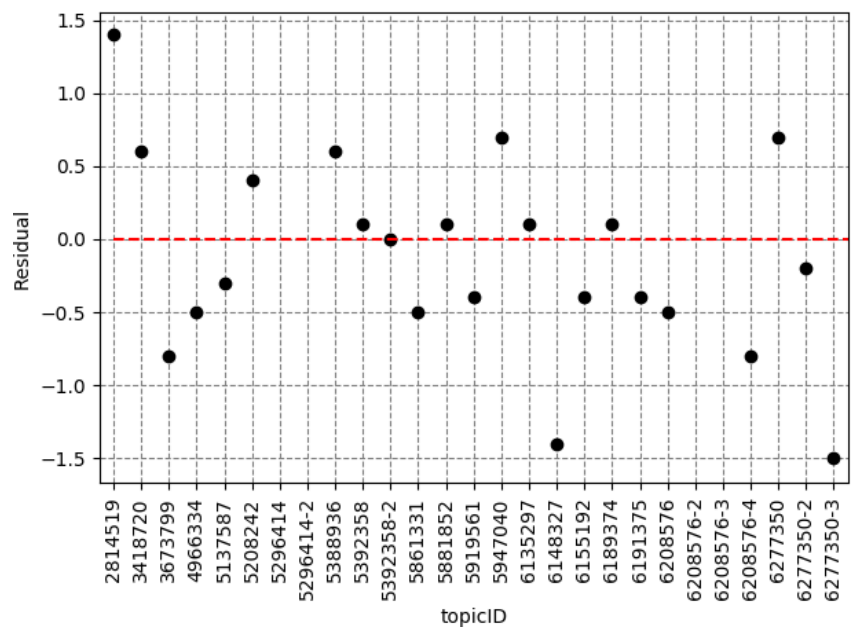

Figure 6. Residuals of measured magnitudes of the earthquakes (Table 1) with average magnitude guesses from users. Earthquakes without any guesses are blank (created using the Matplotlib library of Python). are labeled with their districts. However, the district is more likely to have more than one intensity inside its border, depending on the epicentral distance from the earthquake and the border of the district (e.g., the Gebze district in Fig. 5 has three different MCS values inside its border). To overcome this problem, we have calculated the centroid point of each district and treated the district as a point.

We have calculated the residuals of MCS differences between the predicted and observed values (Fig 7). To do that, we binned the distance between the epicenter and the centroid points with $10 \mathrm{~km}$ intervals from $0-100 \mathrm{~km}$. We combined more distant points with $+100 \mathrm{~km}$ label. The weighted average of the average MCSs are used for the residual calculations. Asymmetric errors are calculated by using the minimum and maximum MCS value for each bin and the predicted MCS. If all data points have the same MCSs, then the errors are not calculated. A line is fitted to residuals when more than one data point is associated in different bins.

It is found that residuals tend to increase with increasing distance. In longer distances, MCS values are more likely to 

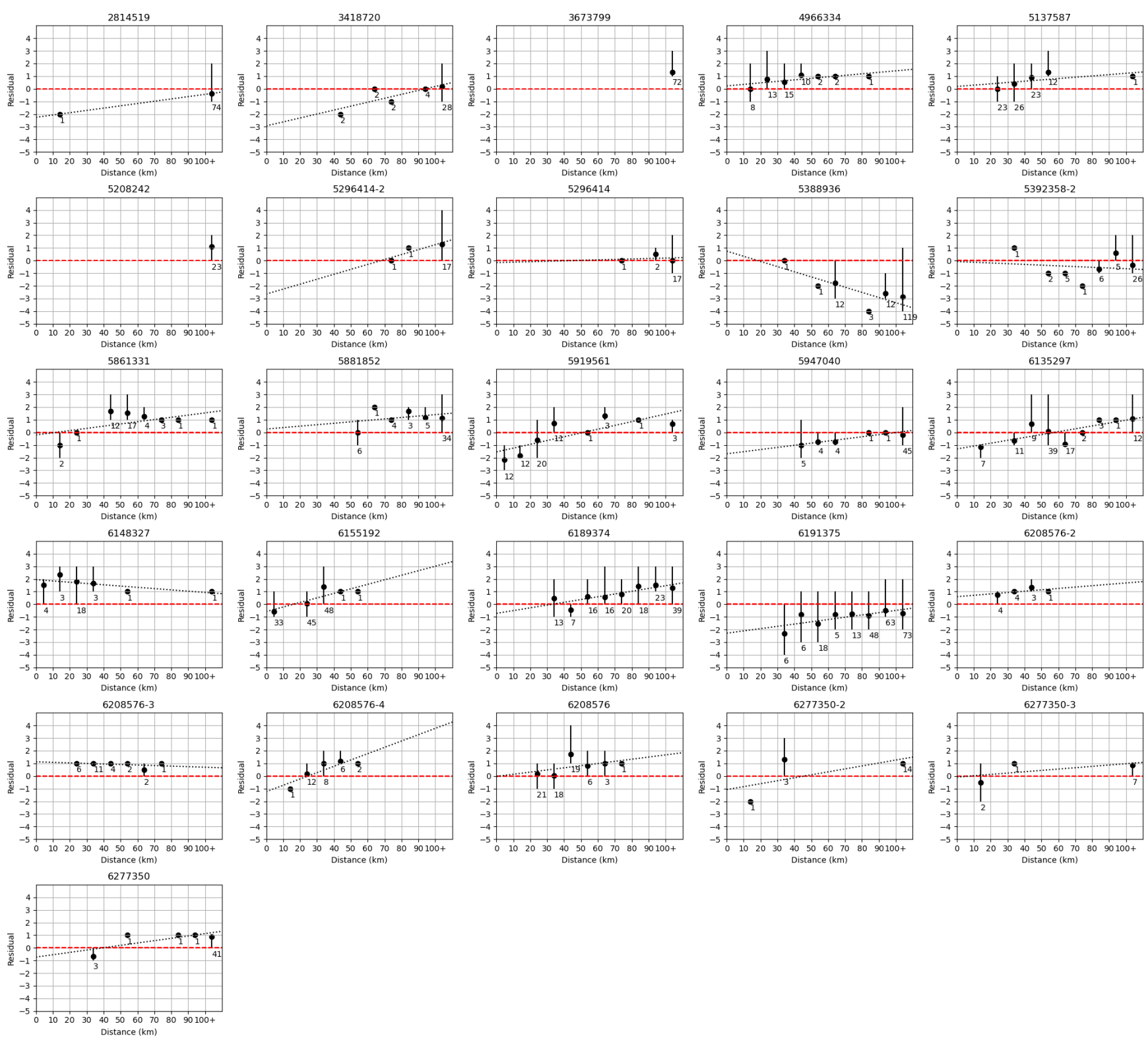

Figure 7. Residuals of predicted and observed MCSs. Red dashed line represents the baseline. Black circles are the residual of the weighted average of the bin. Vertical black lines are the residuals from predicted MCSs and minimum and maximum MCSs that are observed in the bin. The black dotted line is the fitted line to the residual of weighted averages. The number of data points inside the bins is provided beneath each bin point with data (created using Matplotlib library of Python).

be 1 . When there is an entry which states the feeling of the earthquake, it is more likely to have MCS value of 2. This is due to the fact that it is hard to distinguish between MCS 1 and MCS 2 by analyzing the entries. A lack of resolution in terms of expression of the experience limits our distinction levels of intensity. The website is not dedicated to providing exact information on earthquakes.

Furthermore, the population distribution of districts is mostly heterogeneous. An example can be seen in Sect. 4.3. The Silivri district of Istanbul has all of the EMSC data from the coastline. However, it is located in the northern part of the district, for which MCS value is one integer lower with respect to the highly populated coastal area.

The 10 October 2019 Yalova earthquake aftershocks (6208576-2, 6208576-3, and 6208576-4) mostly have MCS 1 for the residuals. The cities of Istanbul and Kocaeli have many reports for which the MCS is equal to 2. However, all the centroid points of the districts are in the area for which MCS is 1.

Despite not having the exact location and having to work with the subjective feelings of the users, it is found that the districts with loose soils have relatively bigger maximum 
MCS values. The Avcilar district in Istanbul has the highest MCS value (3) for the Lesbos earthquake (Sect. 4.1) in the city. In the Istanbul earthquake (Sect. 4.3), Avcrlar also has the highest MCS (6) with respect to other districts with the same epicentral distance. The Avcllar district suffered during the 1999 İzmit earthquake due to the amplified shaking and soft sediments in the district (Tezcan et al., 2002; Ergin et al., 2004; Akarvardar et al., 2009).

Entries that are written from high-rise buildings showed that the users were affected more due to the tendency of these buildings to amplify the motions over longer periods (e.g., the Beşiktaş district during the Istanbul earthquake). Another reason for the higher intensities experienced, with respect to the predicted ones, is the stress experienced during the evacuation of buildings (even if it is not necessary to evacuate). There are unexpectedly high intensity values in various districts for both Istanbul and Yalova earthquakes.

For the Ankara earthquake on 20 August 2019 (6148327), there is a large gap between the predicted and observed MCSs. This is due to the fact that the people of the city of Ankara are not as used to feeling earthquake as people in seismically active cities such as Izmir, Istanbul, and Yalova. Moreover, the epicenter of the earthquake was close to the city center.

The effect of epicentral depth in small earthquakes can be seen in the reports following the Ankara earthquake (Sect. 4.2). The districts of Sincan, Yenimahalle, Mamak, and Çankaya have at least a one degree higher maximum MCS than the predicted ones.

We also analyzed the magnitude guesses in entries with the measured magnitudes. The users of the website try to guess the magnitudes, most probably by comparing their experiences to previous earthquakes. Users living in seismically active regions such as Istanbul, Dardanelles, and Izmir are more likely to feel more earthquakes that occurred at different epicentral distances and magnitudes. On the other hand, users living in regions with lower seismicity, e.g., Ankara, do not have large number of experiences and may think that, when they feel an earthquake, it must be a major one since they do not know the feeling of low-magnitude earthquake. Even though there are good matches in some of the earthquakes, in most of the cases magnitudes are guessed with 0.54 misfit.

In conclusion, entries on the Ekşi Sözlük site can provide intensity distributions of earthquakes with limits. Entries are written in free form, which creates uncertainties in the MCS labeling process. Entries do not reveal the exact position of the data provider, which makes it hard to analyze the differences between observed and predicted MCS values. Despite the limitations, the gathered data have similarities with the predictions. The website can provide near-real-time intensity information after an earthquake.

\section{Future work}

The Ekşi Sözlük site has the potential to provide a wide variety of information through collaboration with the scientific community. The fast response time of the users may be useful for having early information about the intensity distribution. In case of a collaboration, a questionnaire can be embedded for use with the earthquake topics, which would homogenize the data that users write as entries. Depending on the privacy policy of the website and the allowance of a higher precision data in terms of location and building information of the users, high-resolution intensity maps can be created.

Code and data availability. Python codes, data set, and intensity maps can be found at https://doi.org/10.5281/zenodo.3947832 (Ertuncay et al., 2020b). GIS data can be found at https://doi.org/10.6084/m9.figshare.12424352 (Ertuncay et al., 2020a).

Author contributions. DE analyzed the entries on the Ekşi Sözlük website and determined the intensity values. LC created shake maps, and DE visualized the intensity values collected from Ekşi Sözlük and EMSC to create the figures. Results were interpreted by DE, LC, and GC.

Competing interests. The authors declare that they have no conflict of interest.

Acknowledgements. We would like to thank to Enrico Magrin, who was a part of SeisRaM working group of the Department of Mathematics and Geosciences at the University of Trieste (now at Istituto Nazionale di Oceanografia e di Geofisica Sperimentale), for his help in the calculation of the intensities, and Hafize Başak Bayraktar, from the University of Napoli Federico II Department of Structures for Engineering and Architecture, for sharing district level polygons of Turkey. We also would like to thank all the users of Ekşi Sözlük for sharing their experiences on the website. Finally, we would like to thank Selen Caner Ertuncay for proofreading the paper.

Review statement. This paper was edited by Ed Hawkins and reviewed by two anonymous referees.

\section{References}

Agencija Republike Slovenije Za Okolje - ARSO: Environmental Agency of the Republic of Slovenia, available at: http://www. arso.gov.si/potresi/vpra\&scaron;alnik/ (last access: 17 February 2021), 2020.

Akarvardar, S., Feigl, K. L., and Ergintav, S.: Ground deformation in an area later damaged by an earthquake: Monitoring the Av- 
cilar district of Istanbul, Turkey, by satellite radar interferometry 1992-1999, Geophys. J. Int., 178, 976-988, 2009.

Alexa Internet: Top Websites Ranking, available at: https://www. similarweb.com/top-websites/turkey, last access: 10 June 2020.

Anadolu Agency: Istanbul'da 5.8 büyüklügünde deprem, available at: https://www.aa.com.tr/tr/turkiye/ istanbulda-5-8-buyuklugunde-deprem/1594875 (last access: 17 February 2021), 2019 (in Turkish).

Arapostathis, S. G., Lekkas, E., Kalabokidis, K., Drakatos, G., Xanthopoulos, G., Spyroy, N., and Kalogeras, I.: Developing seismic intensity maps from twitter data, the case study of Lesvos Greece 2017 earthquake: Assessments, improvements and enrichments on the methodology, Int. Arch. Photogramm., XLII-3/W4, 5966, 2018.

Bossu, R., Mazet-Roux, G., Douet, V., Rives, S., Marin, S., and Aupetit, M.: Internet users as seismic sensors for improved earthquake response, Eos, Transactions American Geophysical Union, 89, 225-226, 2008.

Bossu, R., Laurin, M., Mazet-Roux, G., Roussel, F., and Steed, R.: The importance of smartphones as public earthquakeinformation tools and tools for the rapid engagement with eyewitnesses: A case study of the $2015 \mathrm{Nepal}$ earthquake sequence, Seismol. Res. Lett., 86, 1587-1592, 2015.

Bossu, R., Landès, M., Roussel, F., Steed, R., Mazet-Roux, G., Martin, S. S., and Hough, S.: Thumbnail-based questionnaires for the rapid and efficient collection of macroseismic data from global earthquakes, Seismol. Res. Lett., 88, 72-81, 2017.

British Geological Survey: BGS E-Mail Earthquake Questionnaire, available at: http://www.earthquakes.bgs.ac.uk/questionnaire/ EqQuestIntroA.html, last access: 10 June 2020.

Cataldi, L., Tiberi, L., and Costa, G.: Estimation of MCS intensity for Italy from high quality accelerometric data, using GMICEs and Gaussian Naïve Bayes Classifiers, B. Earthq. Eng., in press, 2021.

Crooks, A., Croitoru, A., Stefanidis, A., and Radzikowski, J.: Earthquake: Twitter as a distributed sensor system, T. GIS, 17, 124147, 2013.

Department of Engineering of Dokuz Eylul University: 12 Haziran 2017 Izmir Karaburun (Ege Denizi) Depremi Değerlendirme Raporu, available at: http://www.jeofizik.org.tr/resimler/ekler/ 74cb68517e1d6f3_ek.pdf?tipi=1\&turu=H\&sube=4 (last access: 17 February 2021), 2017 (in Turkish).

Earle, P., Guy, M., Buckmaster, R., Ostrum, C., Horvath, S., and Vaughan, A.: OMG earthquake! Can Twitter improve earthquake response?, Seismol. Res. Lett., 81, 246-251, 2010.

Earle, P. S., Bowden, D. C., and Guy, M.: Twitter earthquake detection: earthquake monitoring in a social world, Ann. Geophys., 54, 6, https://doi.org/10.4401/ag-5364, 2012.

Ergin, M., Özalaybey, S., Aktar, M., and Yalcin, M.: Site amplification at Avcrlar, Istanbul, Tectonophysics, 391, 335-346, 2004.

Ertuncay, D., Cataldi, L., and Costa, G.: GISdata, figshare, https://doi.org/10.6084/m9.figshare.12424352, 2020a.

Ertuncay, D., Cataldi, L., and Costa, G.: Dataset and Software, Zenodo, https://doi.org/10.5281/zenodo.3947832, 2020 b.

Fayjaloun, R., Gehl, P., Auclair, S., Boulahya, F., Marthe, S. G., and Roulle, A.: Integrating strong-motion recordings and Twitter data for a rapid shakemap of macroseismic intensity, Int. J. Disast. Risk Re., 52, 101927, https://doi.org/10.1016/j.ijdrr.2020.101927, 2020.
Gallo, A., Costa, G., and Suhadolc, P.: Near real-time automatic moment magnitude estimation, B. Earthq. Eng., 12, 185-202, 2014.

Goltz, J. D., Park, H., Quitoriano, V., and Wald, D. J.: Human Behavioral Response in the 2019 Ridgecrest, California, Earthquakes: Assessing Immediate Actions Based on Data from "Did You Feel It?”, B. Seismol. Soc. Am., 110, 1589-1602, 2020.

Hürriyet: Fuat Oktay'dan Istanbul depremi sonrası önemli açıklamalar, available at: https://www.hurriyet.com.tr/gundem/fuatoktaydan-istanbul-depremi-sonrasi-onemli-aciklamalar41338943 (last access: 17 February 2021), 2019 (in Turkish).

Li, J. and Rao, H. R.: Twitter as a rapid response news service: An exploration in the context of the 2008 China earthquake, The Electronic Journal of Information Systems in Developing Countries, 42, 1-22, 2010.

Liang, W.-T., Lee, J.-C., Chen, K. H., and Hsiao, N.-C.: Citizen earthquake science in Taiwan: from science to hazard mitigation, Journal of Disaster Research, 12, 1174-1181, 2017.

Locati, M., Camassi, R. D., Rovida, A. N., Ercolani, E., Bernardini, F. M. A., Castelli, V., Caracciolo, C. H., Tertulliani, A., Rossi, A., Azzaro, R., D'Amico, S., Conte, S., and Rocchetti, E.: DBMI15, the 2015 version of the Italian Macroseismic Database, Istituto Nazionale di Geofisica e Vulcanologia, https://doi.org/10.6092/INGV.IT-DBMI15, 2016.

Mendoza, M., Poblete, B., and Castillo, C.: Twitter under crisis: Can we trust what we RT?, in: Proceedings of the first workshop on social media analytics, 25 July 2010, Washington, D.C., USA, 71-79, available at: http://snap.stanford.edu/soma2010/ (last access: 22 February 2021), 2010.

Miyabe, M., Miura, A., and Aramaki, E.: Use trend analysis of twitter after the great east japan earthquake, in: Proceedings of the ACM 2012 conference on Computer Supported Cooperative Work Companion, 11-15 February 2012, Seattle, Washington, USA, 175-178, available at: https://dl.acm.org/action/ showFmPdf?doi=10.1145/2145204 (last access: 22 February 2021), 2012.

Robinson, B., Power, R., and Cameron, M.: A sensitive twitter earthquake detector, in: Proceedings of the 22nd international conference on world wide web, 13-17 May 2013, Rio de Janeiro, Brazil, 999-1002, available at: https://dl.acm.org/action/ showFmPdf?doi=10.1145/2487788 (last access: 22 February 2021), 2013.

Sbarra, P., Tosi, P., and De Rubeis, V.: Web-based macroseismic survey in Italy: Method validation and results, Nat. Hazards, 54, 563-581, 2010.

Sieberg, A.: Scala MCS (Mercalli-Cancani-Sieberg), Geologie der Erdbeben, Handbuch der Geophysik, 2, 552-555, 1930.

Swiss Seismological Service: Did You Feel an Earthquake? Report an Earthquake, available at: http://www.seismo.ethz.ch/en/ earthquakes/did-you-feel-an-earthquake/, last access: 10 June 2020.

Tezcan, S. S., Kaya, E., Bal, I. E., and Özdemir, Z.: Seismic amplification at Avc1lar, Istanbul, Eng. Struct., 24, 661-667, 2002.

Turkish Statistical Institute: Information and Communication Technology (ICT) Usage in Households and by Individuals, available at: http://www.turkstat.gov.tr/PreTablo.do?alt_id=1028 (last access: 10 June 2020), 2019.

Wald, D. J., Quitoriano, V., Worden, C. B., Hopper, M., and Dewey, J. W.: USGS "Did You Feel It?", internet-based macroseismic 
intensity maps, Ann. Geophys., 54, 6, https://doi.org/10.4401/ag5354, 2012.

Zentralanstalt für Meteorologie und Geodynamik - ZAMG: Central Institute for Meteorology and Geodynamics of Austria, available at: https://www.zamg.ac.at/cms/de/geophysik/bebenbericht/ index.php, last access: 10 June 2020.
Zielinski, A., Bügel, U., Middleton, L., Middleton, S., Tokarchuk, L., Watson, K., and Chaves, F.: Multilingual analysis of twitter news in support of mass emergency events., in: ISCRAM, Citeseer, Hershey, Pennsylvania, USA, 77-85, https://doi.org/10.4018/jiscrm.2013010105, 2012. 